\title{
Consumer Perception and Willingness to Pay for Organic Vegetables in Ardo Kola and Lau Local Government Area of Taraba State, Nigeria
}

\author{
Aboki E*, Saheed AS, Rukwe DT \\ Department of Agricultural Economics and Extension, Taraba State University, Jalingo, Nigeria
}

\author{
*Corresponding Author \\ Aboki E \\ Article History \\ Received: 12.07.2019 \\ Accepted: 24.07 .2019 \\ Published: 30.07 .2019
}

\begin{abstract}
This study was carried out in other to determine the consumers' perception and willingness to pay for organic vegetables in Ardo Kola Local Government Area of Taraba State. Vegetable production plays an important role in food security and provides food and raw materials for industries, income from sales, unemployment for small household in urban and peri-urban areas in Nigeria. Data collected for this research were analyzed using descriptive statistics and logistic regression model. The empirical findings indicates that majority of the respondents were mainly male, married with mean household of six and mean age of about 41years. Most (37.1\%) of them had completed either primary or secondary education. Many of the respondents agreed with the healthier, better quality, tastier and more expensive characteristics of organic vegetables. About $85 \%$ of them were willing to pay for organically grown vegetables. This shows that in the event of extensive cultivation there is a demand for organically grown vegetables in the study area. However, factors affecting consumer WTP for organically grown vegetables were Age (3.804) number of workers (4.003), and educational level (0.175). These three factors were statistically significant at $5 \%$ and $1 \%$ level of significance respectively. This implies that age, number of workers and educational level of were important factors that significantly influence organic vegetable production in the study area. The study wish to recommend that farmers should be educated on the importance of organic vegetable farming.
\end{abstract}

Keywords: Contingent Valuation, Logistic regression model, Vegetables, Willingness to pay

\section{INTRODUCTION}

Organic Agriculture is a production system that sustains the health of soils, ecosystem and people. It relies on ecological process, biodiversity and cycles adapted to local conditions, rather than the use of inputs with adverse effects. Organic agriculture combines traditions, innovations and science to benefit the shared environment and promote a fair relationships and a good quality of life for all involved [1]. It avoids the use of synthetic pesticides, herbicides, chemical fertilizers, growth hormones, antibiotics or gene manipulation. Instead, organic farmers use a range of techniques that help sustain ecosystems and reduce pollution. It dramatically reduces external inputs by refraining from the use of chemo-synthetic fertilizers, pesticides and pharmaceuticals. Instead, it allows the powerful laws of nature to increase both agricultural yields and disease resistance [2]. Vegetables are a common crop in Nigeria, grown and consumed by different groups of farmers. It production plays an important role in food security and provides food and raw materials for industries, income from sales, unemployment for small household in urban and peri-urban in Nigeria. They can be used in several senses, including culinary, botanical and legal. In culinary terms, a vegetable is an edible plant or its part, intended for cooking or eating raw [3]. Studies show that there has been a dramatic increase in the use of synthetic chemicals, especially Nitrogen (N) fertilizers, since 1945, with a concomitant increase in the production of vegetables. These products, together with new mechanical technology, have led to a high degree of specialization in vegetable growing and the plentiful supply of cheap $\mathrm{N}$ fertilizer has permitted intensive use of the soil [4]. However, the use of chemicals in vegetable production has been identified as a major source of health risk and a cause of extensive environmental damage. According to Lumpkin [5], food safety is a major concern as many of today's vegetable farmers inappropriately use toxic pesticides at pre- and post-harvest stages and this threatens the health of the farmer and consumers as well as contaminating the environment. Lumpkin argues that everyone (poor or rich), must have access to safe vegetables. The reduction of the use of chemical inputs through the adoption of organic agricultural production methods will help achieve these goals. There is growing market for organic vegetables among other products and farmers in the world over are shifting their production practices to meet this challenge. In Nigeria however, organic agriculture had existed by default because of the

Copyright @ 2019: This is an open-access article distributed under the terms of the Creative Commons Attribution license which permits unrestricted use, distribution, and reproduction in any medium for non commercial use (NonCommercial, or CC-BY-NC) provided the original author and source are credited. 
unavailability and sparse use of chemical inputs by farmers. Others adopt the use of animal droppings as manure [6]. Indeed Scialabba [7], notes that non-certified organic systems (indigenous models that follow organic principles by intent or by default) of several million small farmers may represent at least an equivalent share in subsistence agriculture of developing countries.

On the consumer side in Nigeria, there is no much information on the responses to organic products which up to a point can be regarded as new products. The wave of certified organic agriculture has only recently hit the shores of Nigeria. Seyi [8] found that some consumers were aware that some farmers used animal droppings as manure (that study did not determine whether the droppings were used solely or in conjunction with other inputs). Eleven years down the line, a number of scientists and farmers have been cultivating organic vegetables and other crops in various universities, research institutes and farms in the country including the College of Agriculture, Ardo kola, Taraba State of Nigeria. It is expected that these activities will have impacts on the immediate communities and beyond.

Hence, this study set out to determine consumer awareness and perceptions of organic vegetables in Ardo kola Local Government area of Taraba state and the willingness of consumers to pay a premium for the commodity. In addition, the study also intends to see the determinant of willingness to pay for the commodity.

\section{Willingness to pay (WTP)}

Willingness to pay (WTP) is the maximum amount a person would be willing to pay, sacrifice or exchange in order to receive a good or to avoid something undesired, such as pollution. This term stands in contrast to willingness to accept payment (WTA), which is the minimum amount an individual is willing to receive to give up a good or to accept something undesirable [9]. The notion of willingness to pay could be defined as the sum of money representing the difference between consumers' surplus before and after adding or improving a food product attribute [Paul, [10]. According to James [11], tools for measuring WTP (which include the contingent valuation, travel cost and hedonic pricing) can be used to answer questions such as how much consumers are willing to pay for a quality upgrade or what effect a particular government intervention might be. In this regard, consumers' willingness to pay (WTP) for organic food products can be measured using a direct valuation method such as the contingent valuation (CV). The procedure consists of creating a favorable scenario about the subject matter (organic vegetables) follow by a dichotomous choice (DC) question. In the DC question, consumers are asked whether or not they are willing to pay a premium, to buy an organic vegetable instead of a conventional one. Consumers' responses are YES if they are willing to pay more for an organic vegetable or NO otherwise.

It is generally expected that organically produced vegetables are more expensive than their conventional counterpart, mainly due to (the perceived) better quality of products and because of higher production, processing, and distribution costs [12]. Numerous studies have investigated the determinants of consumers' willingness to buy and/or to pay a premium for organic (chemicals free) vegetables and various socioeconomic factors have been cited by these studies. Age, income, and a measure of social class (race) featured as the most important determinant of willingness-to-pay for pesticide-free fresh produce in a study by Batte and Baxter [13]. Paul [10], found that the most likely factors influencing consumers' willingness to-pay for chemical free vegetables are the awareness of chemical residue, availability, label, taste, and consumers' professional category acting as a proxy for income level. The result of the study of [14] shows that income and demographic characteristics of the households are the determinants of consumers' willingness-to-pay higher prices for processed foods with organic content in Kenya. The current study builds on previous literature to isolate determinants of WTP in the Northern environment of Nigeria.

The study was carried out in Ardo kola local government, Taraba state of Nigeria. It is expected that the results will be typical of the Northern region of the country. A total of 70 respondents were randomly selected from the study area. Primary data were collected from the respondents by means of a pre-tested questionnaire which was designed to obtain socioeconomic indices, information on consumer perception about organic vegetables, and willingness to pay premiums for organic vegetables.

\section{MATERIALS AND METHODS Analytical techniques}

Data collected were analyzed by the use of frequency tables and percentages to describe the socioeconomic characteristics of the respondents and the logistic regression model was used to analyze factors affecting willingness to pay.

\section{Model specification}

The contingent valuation method was used to analyze consumer willingness to pay (WTP) and the logistic regression model based on the cumulative probability function was adopted to determine factors influencing consumers' willingness to pay because of its ability to deal with a dichotomous dependent variable. According to [15] the logistic regression analysis is a uni/multivariate technique which allows for estimating the probability that an event will occur or not, through prediction of a binary dependent outcome from a set of variable.

The logit regression model is specified as $y i^{*}=\beta o+\sum_{j=i}^{k} \beta i X i j+u_{i} \ldots \ldots \ldots \ldots \ldots \ldots \ldots \ldots$ [1] Where $y_{i}^{*}$ is commonly known as a "latent" variable which is not observed, what is observed instead is the dummy variable $y_{i}$ such that: $y_{i}=1$ if $y_{i}^{*}>0$ 
otherwise $y_{i}=0$. $\left(X_{i j}\right)$ is a set of explanatory variables, $\beta_{i j}$ are coefficients to be estimated, $U_{i}$ is an error term assumed to follow the logistic distribution;

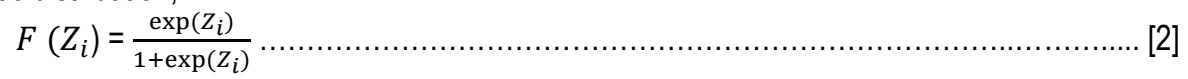

Empirically the logit model is presented as: $\left.\log \left[\frac{p_{i}}{1-P_{i}}\right]=\beta_{0}+\sum_{j=1}^{k} \beta_{I j} X_{i j} \ldots \ldots \ldots \ldots \ldots . .3\right]$

Where $p_{i}=\operatorname{prob}\left(y_{i}=1\right)$ and the left hand side represents the logit or the log of the odds ratio. In this study, the left hand side, represents the dependent variable and is the consumer willingness to pay for organic vegetables (and is measured by the dichotomous variable which will take the value of (one) for willingness to pay and (zero) for not willing to pay. The explanatory variables include consumer socioeconomic characteristics as well as perception of organic product (vegetables).

\section{RESULTS \& DISCUSSION}

\section{Socioeconomic characteristics of respondents}

The result of the socioeconomic characteristics is presented in Table 1. The result revealed that Majority $(62.9 \%)$ of the respondents were male and most $(35.7 \%)$ of them were traders indicating that male are more willing to venture into the business of vegetable production than their female counterpart. The findings also indicate that majority $(70.0 \%)$ of the respondents is married and about $37.1 \%$ of them had completed either primary or secondary education. The mean age of the respondents was about 41 years. Findings further revealed that Expenditure was used as a proxy for income and that Most (38.6\%) of the consumers spend between $\mathrm{N}$ 501 and 750 on fruits and vegetables on a weekly basis. The household sizes of the respondents ranged from one (1). and sixteen (16) with a mean of six.

\section{Willingness to pay for organic vegetables}

The survey results gave an indication that nearly $85 \%$ of the respondents were willing to pay a premium for organic vegetables (figure 1) and a further investigation reveals that about $89 \%$ were willing to pay extra if all their food asides vegetables are grown organically. It was concluded that there is a potential market for organic vegetables in the study area.

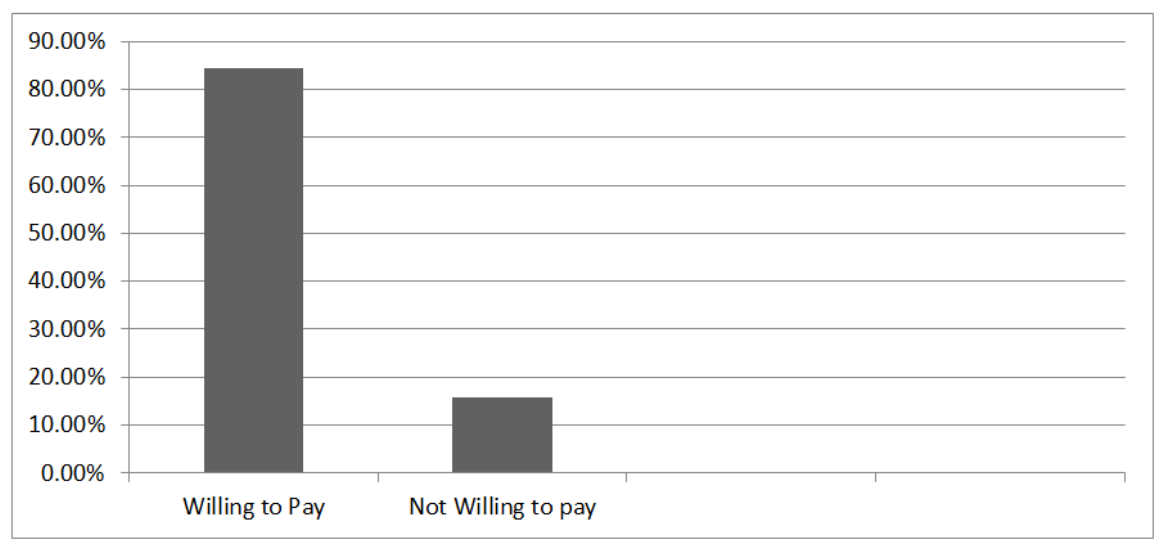

Fig-1: Willingness to pay for organic vegetables

\section{Perception about organic vegetables over conventional vegetables}

The perception about organic vegetable over the conventional vegetables is presented in Table 2. The perceptions varies from different view from the respondents ranging from Healthier, better quality, tastier, more-expensive and no harmful effect. Base on the result of the findings majority $(87.1 \%, 87.1 \%, 75,7 \%, 50 \%$ and $90 \%)$ of the respondents were of the perception that organic vegetables is healthier, better quality, tastier, more-expensive and no harmful effect compare to the conventional vegetables which often have some threat of harm to human health because of chemicals involved in the course of their production.

\section{Determinants of consumer willingness to pay for organically grown vegetables}

The analysis of the logistic regression is presented in Table 3.The results reveals that three factors were found to be responsible for willingness to pay for organically grown vegetables; Education, age, and numbers of workers were the essential factors that contributed significantly to the consumers' willingness to pay for organically grown vegetables in the study area. The constant term is quite significant, indicating goodness of fit of the model. Another measure of goodness of fit is the log likelihood function given by the model which is about $59 \%$. The result in table 3 also gives regression coefficient along with the associated wald statistics, degree of freedom, $p$-value and the $\operatorname{Exp}(\beta)$ which gives the increase in the odds in favour of WTP more when the dichotomous variables changes from 0 to 1 . 
Table-1: Socioeconomic Characteristics of Respondents

\begin{tabular}{|c|c|c|}
\hline Variables & Frequency & Percentages \\
\hline $\begin{array}{l}\text { Age } \\
<25 \\
25-34 \\
35-44 \\
45-59 \\
\text { Above } 60 \\
\text { Total }\end{array}$ & $\begin{array}{l}9 \\
17 \\
27 \\
14 \\
3 \\
70\end{array}$ & $\begin{array}{r}12.9 \\
24.3 \\
38.6 \\
20.0 \\
4.2 \\
100\end{array}$ \\
\hline $\begin{array}{l}\text { Gender } \\
\text { Male } \\
\text { Female } \\
\text { Total }\end{array}$ & $\begin{array}{l}44 \\
26 \\
70\end{array}$ & $\begin{array}{l}62.9 \\
37.1 \\
100\end{array}$ \\
\hline $\begin{array}{l}\text { Marital status } \\
\text { Single } \\
\text { Married } \\
\text { Others } \\
\text { Total }\end{array}$ & $\begin{array}{l}11 \\
49 \\
10 \\
70\end{array}$ & $\begin{array}{l}15.7 \\
70.0 \\
14.3 \\
100\end{array}$ \\
\hline $\begin{array}{l}\text { Educational Level } \\
\text { No formal Education } \\
\text { PRY/Secondary } \\
\text { ND/NCE } \\
\text { HND/BSC } \\
\text { MSC/PhD } \\
\text { Total }\end{array}$ & $\begin{array}{l}16 \\
26 \\
13 \\
10 \\
5 \\
70\end{array}$ & $\begin{array}{r}22.9 \\
37.1 \\
18.6 \\
14.3 \\
7.1 \\
100\end{array}$ \\
\hline $\begin{array}{l}\text { Weekly Expenditure on Vegetables } \\
<250 \\
250-500 \\
501-750 \\
751-100 \\
\text { Above } 1000 \\
\text { Total }\end{array}$ & $\begin{array}{l}7 \\
15 \\
27 \\
6 \\
15 \\
70\end{array}$ & $\begin{array}{r}10.0 \\
21.4 \\
38.6 \\
8.6 \\
21.4 \\
100\end{array}$ \\
\hline $\begin{array}{l}\text { Household Size } \\
<5 \\
5-9 \\
10+ \\
\text { Total }\end{array}$ & $\begin{array}{l}22 \\
35 \\
13 \\
70\end{array}$ & $\begin{array}{l}31.4 \\
50.0 \\
18.6 \\
100.0\end{array}$ \\
\hline $\begin{array}{l}\text { Health consciousness } \\
\text { Yes } \\
\text { No } \\
\text { Don't know } \\
\text { Total }\end{array}$ & $\begin{array}{l}38 \\
10 \\
22 \\
70\end{array}$ & $\begin{array}{l}54.3 \\
14.3 \\
31.4 \\
100\end{array}$ \\
\hline $\begin{array}{l}\text { Occupation } \\
\text { Trader } \\
\text { farmer } \\
\text { Civil servant } \\
\text { Others } \\
\text { Total }\end{array}$ & $\begin{array}{l}25 \\
17 \\
17 \\
11 \\
70\end{array}$ & $\begin{array}{l}35.7 \\
24.3 \\
24.3 \\
15.7 \\
100\end{array}$ \\
\hline
\end{tabular}

Source: survey Data, 2016. 
Table-2: Perception about Organic Vegetables over Conventional Vegetables

\begin{tabular}{|l|c|c|}
\hline Index of perception & Frequency & Percentages \\
\hline Healthier & & \\
Disagree & 2 & 2.9 \\
Undecided & 7 & 10.0 \\
Agree & 61 & 87.1 \\
Total & 70 & 100 \\
\hline Better Quality & & \\
Disagree & 1 & 1.4 \\
Undecided & 8 & 11.4 \\
Agree & 61 & 87.1 \\
Total & 70 & 100 \\
\hline Tastier & & \\
Disagree & 3 & 4.3 \\
Undecided & 14 & 20.0 \\
Agree & 53 & 75.7 \\
Total & 70 & 100 \\
\hline More expensive & & \\
Disagree & 6 & 8.6 \\
Undecided & 29 & 41.4 \\
Agree & 35 & 50.0 \\
Total & 70 & 100 \\
\hline No harmful effect & 2 & \\
Disagree & 2.9 \\
Undecided & 5 & 7.1 \\
Agree & 63 & 90.0 \\
Total & 70 & 100 \\
\hline \multicolumn{2}{|c|}{ Source: Survey Data, 2016} \\
\hline
\end{tabular}

Table-3: likelihood estimate of logistic Regression Model (Dependent variable= WTP)

\begin{tabular}{|l|l|l|l|l|l|l|}
\hline Variables & B & Standard Error & Wald & df & P-value & Exp $(\boldsymbol{\beta})$ \\
\hline Education & $0.175^{* *}$ & 0.577 & 0.920 & 1 & 0.044 & 34.844 \\
\hline Age & $3.804^{* * *}$ & 0.703 & 0.966 & 1 & 0.000 & 30.999 \\
\hline Health consciousness & 0.775 & 0.620 & 1.564 & 1 & 0.211 & 2.171 \\
\hline Taste & 1.689 & 0.250 & 3.245 & 1 & 0.985 & 19.085 \\
\hline Number of workers & $4.003^{* * *}$ & 0.723 & 18.756 & 1 & 0.000 & 6.345 \\
\hline Household size & -0.088 & 0.101 & 0.751 & 1 & 0.386 & 0.916 \\
\hline Expenditure & 0.006 & 0.354 & 0.000 & 1 & 0.985 & 1.245 \\
\hline Constant & $1.680^{* * *}$ & 0.328 & 26.157 & 1 & 0.000 & 5.364 \\
\hline Log -likelihood function $=59.013$ \\
\hline
\end{tabular}

\section{CONCLUSIONS}

The result obtained from this study agrees with the popular opinion of WTP but disagree with the study of [12] where Taste was an important factor affecting willingness to pay for organically grown vegetables in Ghana. Further, logit analysis showed that Age, Number of workers and Educational level of consumers are factors influencing willingness to pay for organic vegetables. Accordingly, it could be stated that educating the populace on the health benefits of organic product would enhance the demand for organic vegetables. The variable Age which was found to be positively influencing the willingness to pay for organic vegetables might be because majority $(54.3 \%)$ of the consumer in the study area was found to be health conscious and health consciousness increases with Age. Similarly, the variable "Number of Workers" was also found to be positively influencing the willingness to pay for organic vegetable. A possible reason is that consumers with large number of workers might be willing to share the cost of purchasing organic vegetables since majority (50\%) agrees that organic vegetables are more expensive than their conventional counterpart.

The study has also shown that consumers agree that organic vegetables are more expensive, healthier, and tastier, have no harmful effects and are of better quality than the conventional vegetables and majority (85\%) were willing to pay more for this commodity. This shows that in the event of extensive cultivation, there is a ready market in the study area. 
The study also provides contributions to the existing literature by analyzing the determinants of WTP for organic vegetables. Hence the result of the study would enrich understanding of consumer WTP for organic vegetables in the study area and provide a guide for organic farmers.

\section{RECOMMENDATIONS}

Based on the findings, the researchers wish to recommend that:

- Farmers in the study area need to be educated on the importance of organic vegetables farming

- Government and private organizations should support and encourage farmers who want to venture into the business organic vegetables farming by giving them credit in form of loan.

- The populace should be encouraged to consume vegetables that are organically oriented in nature.

\section{REFERENCES}

1. Haas G. (2015). The Organic Agriculture Approach in Organic Agro expertise. internet site: http://www.ifoam.org/en/organiclandmarks. (Accessed January 10, 2015)

2. Adeoye, G. O. (2005). Organic agriculture: a review and possible adoption for food security in Nigeria. In Proceedings of the 1st National Conference on Organic Agriculture in Nigeria.

3. Vainio, Harri \& Bianchini, F.( 1990). Fruits and Vegetables. IARC: 2

4. Kelly, W. C. (1990). Minimal use of synthetic fertilizers in vegetable production. HortScience, 25(2), 168-169.

5. Adamu, C. O., Oose, M. O., \& Bello, N. A. (2015). Farmers' Perception towards Organic-based Vegetable Produc-tion in llaro Agricultural Zone, Ogun State, Nigeria. International Journal of Applied Agriculture and Apiculture Research, 11(1-2), 115-122.

6. Dipeolu, A. O., \& Akinbode, S. O. Consumer perceptions of organic produce in Abeokuta" in FO Olasantan et al. In Organic Agriculture for Sustainable Food Security Proceedings of the 1st National Conference of the Organic Agricultural Project in Tertiary Institutions in Nigeria (OAPTIN) held at the University of Agriculture, Abeokuta, Nigeria, 25: 191-196.

7. Scialabba, N.E. (2007). Organic Agriculture and Food Security, Food and Agriculture Organization of the United. Nations. ftp:/ftp.fao.org/paia/organic/ofs/OFS P.15.

8. Seyi, A. (2012). Organic Farming solution to abuse of Agrochemicals: A Seminar delivered on Tuesday $3^{\text {rd }}$ April 2012. Tribune.com.ng/index.php/wealth creation. Political and social factors affecting organic farming sourced from Tribune.com.ng/index.php/wealth creation ,.

9. Gil, J. M., Gracia, A., \& Sanchez, M. (2000). Market segmentation and willingness to pay for organic products in Spain. The International Food and Agribusiness Management Review, 3(2), 207-226.

10. Paull, J. (2011). Nanomaterials in food and agriculture: The big issue of small matter for organic food and farming.

11. James, J. S. (2002). Research Project outline on Consumer valuation of Food quality Attributes. Office of the Dean, College of Agricultural Sciences. The Pennsylvania University.

12. Barkley, A. (2002, August). Organic food growth: Producer profits and corporate farming. In Presentation at the Risk and Profit Conference, Dept. of Agricultural Economics, Kansas State University, Manhattan, Kansas.

13. Baxter, B. (2006). Who's buying organic? Demographics 2006, hartbeat taking the pulse of the marketplace, May 17.

14. CBN. Guidelines for utilization and access to agricultural loan, sourced from www.cenbank.org/out/circulars/DFD/2. 2011

15. Coulibaly, O., Nouhoheflin, T., Aitchedji, C. C., Cherry, A. J., \& Adegbola, P. (2011). Consumers' perceptions and willingness to pay for organically grown vegetables. International journal of vegetable science, 17(4), 349-362. 